\title{
THE APPLICATION OF SECTION 197 OF THE LABOUR RELATIONS ACT IN AN OUTSOURCING CONTEXT (PART 1)
}

\author{
Lynn Biggs \\ BCom LLB LLM \\ Lecturer \\ Nelson Mandela Metropolitan University \\ Port Elizabeth
}

\section{SUMMARY}

Section 197 of the Labour Relations Act (LRA) in both its original form and in its current form caused much confusion and debate. Originally it was interpreted that section 197 allowed for the automatic transfer of employees in cases where there was a transfer of the whole or part of a business, trade or undertaking as a going concern. That meant that the contracts of employment transfer to the new owner and that the employees could not refuse to be transferred. Various judges were tasked with interpreting this section in its original form and thus different interpretations emerged, with the Labour Appeal Court ultimately deciding in the NEHAWU $v$ University of Cape Town matter that employers involved in the transfer can decide between them, not to transfer the employees. The LAC further held that "outsourcing" does not necessarily entail a transfer of a business.

Section 197 was amended in 2002 and the effect of the provisions is that the old employer is not required to seek the consent of the employees before their contracts are transferred and that the employment contracts transfer automatically. However, the current section has also raised some difficulties especially relating to: when does a transfer of a business as a going concern take place; what constitutes a "business"; when is an entity part of a business, trade, undertaking or service? A more glaring controversy relates to whether section 197 applies to "second-generation contracting out or outsourcing".

All provisions of the LRA should be interpreted in the context of advancing economic development, social justice, labour peace and democratisation of the workplace. One of the primary objects of the LRA is to give effect to and to regulate the fundamental rights of the Constitution of the Republic of South Africa, 1996. Thus section 197 is to be interpreted in light of the objectives of the LRA as well as to promote the spirit, purport and objects of the Bill of Rights.

The common law and international law are both important sources of comparison. The common law allows employers who transfer businesses free to decide whether or not the transfer will include the employees of the transferor. International law, particularly the European Union and the United Kingdom, favour the approach that when an entity is transferred, it retains its identity after the transfer and the safeguarding of employee rights in the context of business transfers. European and English jurisprudence have shown that almost any combination of events can constitute a transfer of a business. 
Case law regarding the current section 197 once again raised debate especially relating to the interpretation of the word "service" which was added to section 197 by the amendment. The LAC in the SAMWU $v$ Rand Airport Management Company ruled that a contract to outsource for example gardening functions is a service within the meaning of section 197. Thus such arrangements could result in the automatic transfer of affected employees from the outsourcer to the contractor.

Further confusion and debate have arisen as a result of the decision of the COSAWU $v$ Zikhethele Trade (Pty) Ltd matter which held that there may be automatic transfers in cases of second-generation outsourcing, meaning when the outsourcing contract changes hands from one contractor to another, section 197 would apply and employees concerned would transfer automatically. The implications of such an interpretation could have vast consequences.

In conclusion, it all boils down to the interpretation and application of section 197. Some authors are of the view that section 197 should be widely interpreted; thus the proper protection of employee rights may require the courts to construe section 197 more widely than narrowly. The preferred interpretation is that of Wallis who is of the view that section 197 should be confined to the transfer of businesses and to that subject alone.

\section{$1 \quad$ INTRODUCTION}

Section $197^{1}$ of the Labour Relations Act ${ }^{2}$ (LRA) has long been a source of confusion and concern. ${ }^{3}$ It has generally been thought that when one company transfers part of its business to another, the contracts of the affected workers transfer automatically to the other company. However, at least one judge of the Labour Court thought otherwise. Mlambo $\mathrm{J}$ in NEHAWU v University of Cape Town ${ }^{4}$ held that "outsourcing" does not necessarily entail a transfer of business. ${ }^{5}$

Players on the corporate stage constantly change their make-up and composition. ${ }^{6}$ Companies are increasingly restructuring to focus on what is termed "core-business", and many services and functions once provided "inhouse" are being outsourced, to be provided by independent service providers engaged on a commercial basis. ${ }^{7}$ Not all outsourcing arrangements will amount to a transfer of a going concern, but this is a possibility. ${ }^{8}$ All relevant facts have to be weighed up and there is no single easy test. ${ }^{9}$

S197. Transfer of contract of employment.

Act 66 of 1995.

Bosch "Aluta Continua, or Closing the Generation Gap: Section 197 of the LRA and its Application to Outsourcing" 2007 Obiter 84.

[2000] 7 BLLR 803 (LC).

5 Grogan and Gauntlett "Outsourcing Workers - A Fresh Look at Section 197" October 2000 EL 15.

6 Grogan and Gauntlett "Going Concerns: Unilateral Transfers of Service Contracts" June 1999 EL 14.

7 Van Niekerk, Christianson, McGrogor, Smit and Van Eck Law@work (2008) 299.

8 Beaumont "Coping with Corporate Re-organisation: Outsourcing - Must Sub-contractors Take over Client's Staff?" 19993 Beaumonts Service Beaumont Express 556.

$9 \quad$ lbid. 
The provisions of the original section 197 (prior to the 2002 amendments), Seady AJ in Schutte $v$ Powerplus Performance (Pty) $L t d,{ }^{10}$ held "were part of the Act's mechanisms to provide security of employment in times of change".

It was generally thought that the original section 197 was intended to achieve two objectives. The first to protect employees whose employers decide to sell or otherwise transfer their businesses to others; the second is to lessen the burden that the law would otherwise place on employers who engage in that exercise. ${ }^{11}$

Prior to the enactment of the LRA, the Industrial Court had begun to develop guidelines to protect employees when businesses were transferred, but had not determined that contracts should transfer automatically in these circumstances. $^{12}$

Case law relating to the transfer of businesses will be considered in the light of the original section 197 as well as with regard to outsourcing arrangements. However, reliance placed on case law around the original section 197 is to be treated with caution because of the amendments to the LRA in 2002.

It was anticipated that the 2002 amendments to the LRA would iron out some of the more glaring anomalies that surfaced in the new labour relations regime since its inception. ${ }^{13}$

However, in both its original and amended forms, section 197 continued to generate much debate. Much of the debate turned on the question: when does a transfer of a business as a going concern actually take place? ${ }^{14}$

Despite the amendments to section 197, subsequent court decisions have demonstrated that the applicability of the section remains contested terrain. ${ }^{15}$

The application of section 197 has given rise and still could give rise to numerous difficulties. These difficulties include: what constitutes a "business" for the purposes of section 197; and particularly around when an entity is part of a business, trade, undertaking or service. ${ }^{16}$

The word "service" was introduced into section 197 in 2002 and seems to have extended the reach of this section to cover many outsourcing contracts. ${ }^{17}$

Many of the cases shaping the scope of section 197 have related to cases involving so-called outsourcing. ${ }^{18}$

\footnotetext{
[1999] 2 BLLR 169 (LC).

Grogan "A Twist on Transfers: LAC Re-interprets Section 197" June 2002 EL 9.

Van Niekerk et al 300.

Grogan and Gauntlett "Welcome Changes" October 2000 EL 3.

Grogan and Gauntlett "Second-generation Outsourcing: The Reach of Section 197" October 2005 EL 10.

15 Bosch 2007 Obiter 84.

16 Bosch "Of Business Parts and Human Stock: Some Reflections on Section 197(1)(a) of the Labour Relations Act" 2004 ILJ 18651882.

17 Beaumont 20057 Beaumonts Service Beaumont Express 135.

18 Bosch 2007 Obiter 85.
} 
In terms of current section 197, an outsourcing arrangement may constitute a transfer of a business as a going concern. But what is the position when the outsourcer cancels the contract with the original contractor and concludes a new contract with another? ${ }^{19}$

Outsourcing was dealt a blow when the Labour Court in SAMWU $v$ Rand Airport Management Company (Pty) $L t d^{20}$ decided that such arrangements may result in the automatic transfer of affected employees from the outsourcer to the contractor; now the Labour Court in COSAWU v Zikhethele Trade (Pty) $L t d^{21}$ has held that there may be further transfers when the outsourcing contract changes hands. ${ }^{22}$

The current controversy relates to whether the section can apply to socalled "second-generation contracting-out". ${ }^{23}$

\section{THE CONSTITUTION, THE COMMON LAW, AND INTERNATIONAL INFLUENCES}

\section{The constitutional effect}

The LRA's stated primary purposes are to give effect to and to regulate the fundamental rights conferred by section 27 of the Interim Constitution, ${ }^{24}$ and to provide a framework within which employees and their trade unions, employers and employers' organisations can bargain collectively to determine wages, terms and conditions of employment and other matters of mutual interest. Any person or court interpreting the LRA must give effect to the Act's primary objects and ensure that its provisions are in compliance with the Constitution ${ }^{25}$ and with the public international law obligations of the republic. $^{26}$

Employees are entitled under section 23 of the Constitution to fair labour practices and this, together with the objectives of the LRA, are to be used in interpreting a section such as section 197 of the LRA. The right to fair labour practices entrenched in section 23(1) is an unusual constitutional right. It is not a right found in other constitutions. ${ }^{27}$

In the Constitutional Court's judgment in the NEHAWU case, ${ }^{28}$ Ngcobo J assessed the fairness component of the right to fair labour practices, which he defined in terms of a balancing or accommodation of often competing interests:

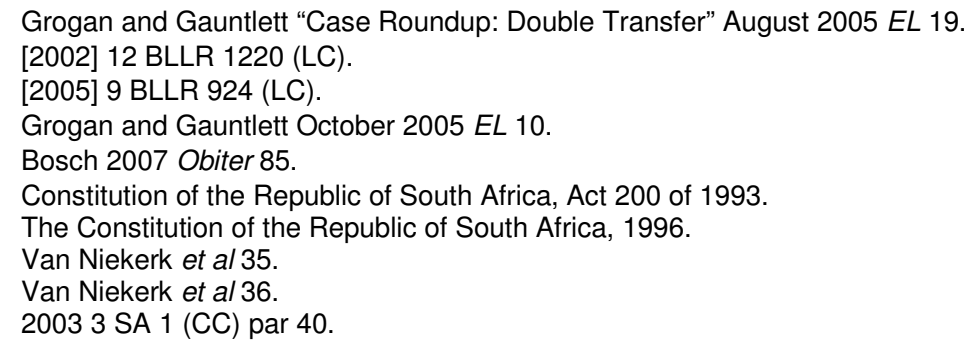


"In my view the focus of section 23 (1) is, broadly speaking, the relationship between the worker and the employer and the continuation of that relationship on terms that are fair to both. In giving content to that right, it is important to bear in mind the tension between the interests of the workers and the interests of the employers that is inherent in labour relations. Care must therefore be taken to accommodate, where possible, these interests so as to arrive at the balance required by the concept of fair labour practices. It is in this context that the LRA must be construed."

Section 39(2) of the Constitution requires courts to promote the spirit, purport and objects of the Bill of Rights when interpreting legislation. That is emphasised by the LRA itself, which states that one of the primary objects of the Act is to give effect to the right to fair labour practices. It also stipulates that the Act must be interpreted to give effect to its primary objects and the Constitution. ${ }^{30}$

\section{Common law}

Under the common law, the closure of a corporate employer (whether by insolvency, sale, merger, take-over or for any other cause) resulted in the termination of the contracts of employment between the employer and the employees. In these circumstances, the employer was required to terminate the contracts of the employees on notice. An employer contemplating closure could not under the common law compel its employees to work for another employer. ${ }^{31}$

The common law, based historically as it is on the relationship between what was termed "master and servant", regards the employment relationship as personal. The common law respects an employee's right to choose his or her employer, and an employer's right to choose whom it wishes to employ. The common law also provides that in the absence of the employee's consent, an employment contract cannot be assigned from one employer to another. In the absence of consent to a transfer, the employment relationship comes to an end, and the employee has no right to continued employment by any new owner of the business. ${ }^{32}$

Under the common law employees were deemed to have been discharged by the former employer, whether or not they had been offered positions in the transformed structure. If they did not want to work under it, they could not be forced to do so. That was because an employment contract was deemed in law to be one of so personal a nature that it could not be transferred from one employer to another without the employee's consent. This was one difference between the free market employee and the slave. ${ }^{33}$

The rule against non-consensual transferability of employment did not create major problems under the common law. The reluctant employee

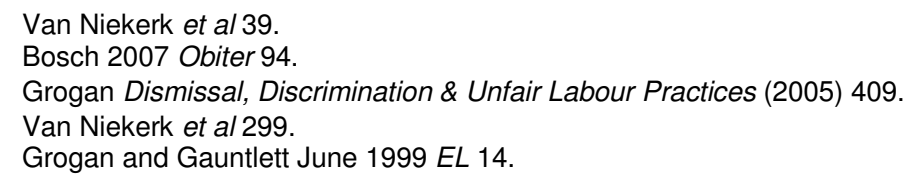


could simply be paid off on notice. However, as the size of the pay-outs to which employees became entitled by law or by collective agreement increased, so employees became a potential major factor in the corporate jungle. $^{34}$

In terms of the generally accepted approach to statutory interpretation, the legislature does not intend to change the common law unless it expressly or by necessary implication says otherwise. ${ }^{35}$ The common law leaves employers who transfer businesses free to decide whether or not the transfer will include the transferor's employees. ${ }^{36}$

The Industrial Court recognized the need to protect employees under these circumstances and noted the absence of any mechanism for the transfer of employees' contracts of employment to the purchaser, but failed to offer a remedy.

\section{International considerations}

\section{Transfer of business}

International decisions on the transfer of a business can be classified into broad and narrow interpretations. ${ }^{38}$

The European Court of Justice has favoured a broader interpretation and the converse is applicable in the United Kingdom (UK). There have been some cases which have regarded the outsourcing of service or the mere transfer of an activity or services, as sufficient to constitute a transfer of a business whereas other decisions have held that for this outcome there be some concomitant transfer of significant assets (tangible or intangible), or the taking over by the new employer of a major part of the workforce. ${ }^{39}$

The test for the transfer of a going concern laid down by the European Court of Justice for the purposes of the application of directives safeguarding employee rights in the context of business transfers, is that when an economic entity is transferred it retains its identity after the transfer. This involves a two-stage test, namely (a) whether there is an "economic entity" that (b) retains its identity after the transfer. Bosch is of the view that a similar approach should be adopted in South Africa. ${ }^{40}$

There have been some interesting decisions in the UK, for example, that a transfer of an undertaking has arisen where one sub-contractor is

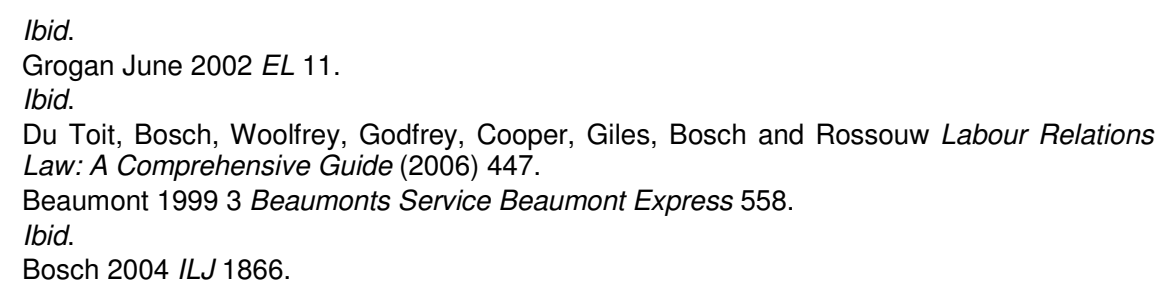


substituted for another. In other words, there was an existing outsourcing arrangement, which was then moved from supplier A to supplier $B{ }^{41}$

Seady AJ in Schutte $v$ Powerplus Performance (Pty) $L t d,{ }^{42}$ turned for guidance to interpretations of the Acquired Rights Directive of the Council of the European Communities:

"Numerous factors have been regarded as indicative of a transfer of a business, but no single factor has been regarded as conclusive of this determination. For example, a sale of assets may indicate a transfer within the meaning of the Directive, but not necessarily. Conversely, the fact that no assets were sold does not mean that there has been no transfer of a business. Likewise, the transfer of a significant number of employees and the immediate continuation or resumption of a service or function is regarded as indicative, but not conclusive of a transfer ...

Seady AJ also considered the jurisprudence of the English courts in which it had been held that transfers of refuse collection, cleaning and paediatric services from a local authority to outside contractors were transfers within the meaning of British legislation. Although they were decided under specific legislation, the judgments of the English courts indicate that our courts could well go the same way. ${ }^{4}$

The European Court of Justice has noted that the object of the transfer is an "organised grouping of persons and assets facilitating the exercise of an economic activity which pursues a specific objective". ${ }^{4}$ But that court has also stressed that the mere fact that such an activity is sold does not necessarily mean that it amounts to a "transfer of business" for the purposes of the directive that governs such matters in Europe. That is only the beginning of the enquiry. ${ }^{46}$

In the European and UK jurisprudence there has been a struggle between the courts on the one hand and business entities on the other over what constitutes the transfer of a business. The cases show that almost any combination of events can potentially constitute a transfer of a business. ${ }^{47}$

It is unnecessary for the transfer to arise from a contract and it is also unnecessary for there to be any relationship, contractual or otherwise, between transferor and transferee.

The European and English jurisprudence are neither clear nor consistent. There are statements in judgments that suggest that there are factual findings that the situation presented is a transfer of undertakings when it is nothing more than statements that such situations could possibly be transfers of undertakings. ${ }^{49}$

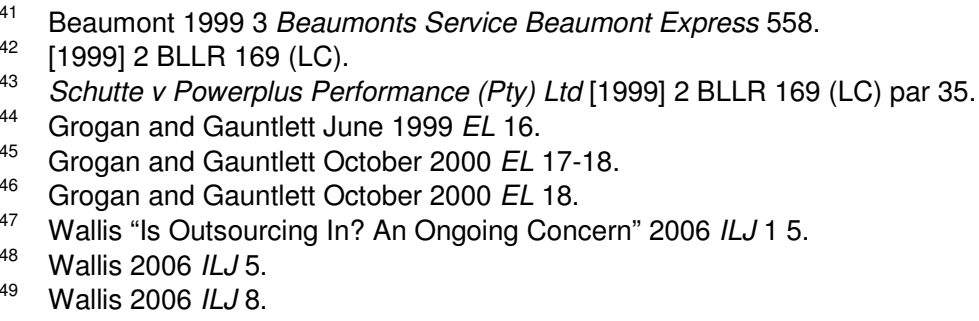




\section{What happens to contracts of employment?}

Zondo JP in NEHAWU v University of Cape Town, ${ }^{50}$ began by observing that there was "no doubt" that the drafters of the LRA were seeking to give effect to a directive issued by the Council of the European Communities in 1977, dealing with the transfers of businesses "as a result of a legal transfer or merger", the directive provides, among other things, that "the transferor's rights and obligations arising from the contract of employment or from an employment relationship existing on the date of a transfer, be transferred to the transferee. Article 4 of the directive states that the transfer of a business "shall not in itself constitute grounds for dismissal by the transferor". ${ }^{51}$

The United Kingdom Transfer of Undertakings (Protection of Employment) Regulations, provides that, subject to certain exceptions, the transfer of a business "shall not operate so as to terminate the contract of employment of a person by the transferor ... but any such contract which would otherwise have been terminated by the transferee shall have effect after the transfer as if originally made between the person so employed and the transferee.".52

When dealing with the effects of the transfer of a business on the employment contracts of the transferring employer, the European directive and the UK regulations have a virtue which the original section 197 [See Chapter 3 below] lacks: clarity. ${ }^{53}$ Both the directive and the regulations leave no doubt that, when a business changes hands, so too, do the contracts of employment attached to that business. Both instruments leave no doubt that, in such circumstances, the transfer of contracts of employment is automatic. This means that the consent of the employers is quite irrelevant in this regard; the only choice that the employers have is not to agree to the business transfer itself. ${ }^{54}$

Zondo JP was forced to go to some length when seeking to establish whether the similarities and differences between the UK regulations and the European directive and the original section 197 indicate whether or not the original section 197 should be read as if it also seeks to ensure that the contracts of employees affected by transfer or merger of the businesses of their employers transfer automatically, unless the employees agree otherwise. ${ }^{55}$

According to Zondo JP, the only material difference in this regard between the original section 197 and the European directive is that neither the directive nor the UK regulation uses the term "going concern" when they deal with transfers of businesses. ${ }^{56}$

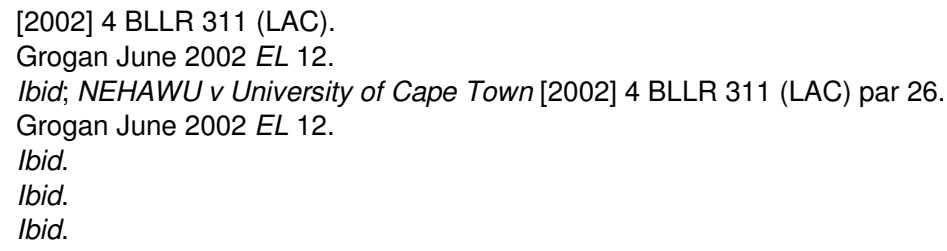


The European directives and the UK regulations are solely and specifically directed at the protection of employees' continuity of employment. $^{57}$

\section{Compliance with international law}

The long title of the LRA sets out one of the objectives of the Act as "to change the law governing labour relations and, for that purpose - to give effect to the public international law obligations of the Republic relating to labour relations".

Section 3(c) of the LRA requires that "any person applying this Act must interpret its provisions - (c) in compliance with the public international law obligations of the Republic".

The Constitutional Court (CC) in NEHAWU v University of Cape Town ${ }^{58}$ said that the foreign jurisprudence can "provide some insight for a proper interpretation and application of section 197". ${ }^{59}$

The Labour Court in COSAWU v Zikhethele Trade (Pty) Ltd ${ }^{60}$ held that foreign jurisprudence has the status of a clear guide to the content of our law. Wallis's view is that Zikhethele's elevation of the status of foreign jurisprudence is a fundamental error particularly in relation to a crucial departure from the plain language of section 197.

Wallis says that "the proper approach must be to start with the language of our own legislation, not some preconception of what the law should be or some preconception of what the law should offer to employees or what rights it should confer upon employers in these diverse circumstances". ${ }^{62}$

However, Bosch argues that our courts are not bound to follow the European courts, but should be guided by their experience. ${ }^{63}$

\section{SECTION 197 OF THE LRA PRIOR TO THE 2002 AMENDMENT}

\section{Introduction}

While the common law rule may have been appropriate in an era when employment was more often than not a relationship between individuals, a personal relationship between employer and employee is no longer the hallmark of employment. The disposal of a business poses concerns for

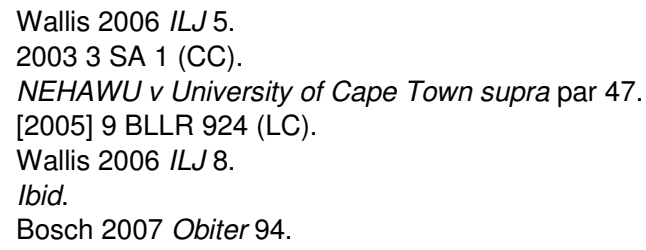


employees about their work security rather than their freedom of contract and the identity of any new employer. ${ }^{64}$

The drafters of the LRA claimed to have resolved the common law problem by making provision for the "automatic transfer of contracts of employment to the transferee provided that the employees consent to the transfer". ${ }^{65}$

However, key concepts used in the section were not defined; the section used words and phrases such as "transfer" and "transfer as a going concern" without defining them and at the same time use of this phrase limited the sphere of application of the original section $197 . .^{66}$

\section{Analysis of the original section 197}

The original section 197, prior to the substitution of section 197 by section 49 of the Labour Relations Amendment Act, ${ }^{67}$ reads as follows:

"197. Transfer of contract of employment

(1) A contract of employment may not be transferred from one employer (referred to as "the old employer") to another employer (referred to as "the new employer") without the employee's consent, unless -

(a) the whole or any part of a business, trade or undertaking is transferred by the old employer as a going concern; or

(b) the whole or a part of a business, trade or undertaking is transferred as a going concern -

(i) if the old employer is insolvent and being wound up or is being sequestrated; or

(ii) because a scheme of arrangement or compromise is being entered into to avoid winding-up or sequestration for reasons of insolvency.

(2) (a) If a business, trade or undertaking is transferred in the circumstances referred to in subsection (1)(a), unless otherwise agreed, all the rights and obligations between the old employer and each employee at the time of the transfer continue in force as if they were rights and obligations between the new employer and each employee and, anything done before the transfer by or in relation to the old employer will be considered to have been done by or in relation to the new employer.

(b) If a business is transferred in the circumstances envisaged by subsection (1)(b), unless otherwise agreed, the contracts of all employees that were in existence immediately before the old employer's winding-up or sequestration transfer automatically to the new employer, but all the rights and obligations between the old employer and each employee at the time of the transfer remain rights and obligations between the old employer and each employee, and anything done before the transfer by the old employer in respect of each employee will be considered to have been done by the old employer.

Van Niekerk et al 299.

Grogan and Gauntlett June 1999 EL 14

66 Basson, Christianson, Garbers, Le Roux, Mischke and Strydom Essential Labour Law 5ed (2005) 171.

67 Act 12 of 2002. 
(3) An agreement contemplated in subsection (2) must be concluded with the appropriate person or body referred to in section 189(1).

(4) A transfer referred to in subsection (1) does not interrupt the employee's continuity of employment. That employment continues with the new employer as if with the old employer.

(5) The provisions of this section do not transfer or otherwise affect the liability of any person to be prosecuted for, convicted of, and sentenced for, any offence."

The original section 197 consists of five subsections. The first provides that a contract of employment may not be transferred without the employee's consent other than in the circumstances of a sale of a business as a going concern. The second requires the terms of a contract of employment to remain unchanged if the contract is transferred in the circumstances referred to in the first subsection. All the old employer's rights and obligations are accordingly transferred to the new employer. The second does, however, allow all the terms to be changed by agreement and the third subsection clarifies that such agreement should be with the appropriate person or body referred to in section 189(1). The fourth subsection stipulates that, in the event of a transfer of a contract of employment as contemplated in the first subsection, there is to be no interruption in the continuity of the employee's period of employment. Lastly, the fifth subsection clarifies the limits of the transfer of obligations in terms of the second subsection by providing that criminal liability in relation to employment issues is not transferred to the new employer with the contract of employment. ${ }^{68}$

The original section 197 provided, first, that when employers transfer the whole or part of the business as a going concern, the contracts of employment transfer to the new owner; second, that employees cannot refuse to be transferred with the business, thus ensuring that the transferring employer is not compelled to retrench the employees and pay them severance benefits. ${ }^{69}$

The original section 197 began by saying that a contract of employment may not be transferred from one employer ("the old employer") to another employer ("the new employer") without the employees' consent, unless two sets of circumstances applied. ${ }^{70}$ One was where "the whole or part of a business, trade or undertaking is transferred by the old employer as a going concern". ${ }^{71}$ The other was where the business, trade or undertaking is transferred, again in whole or in part, if the old employer is insolvent and is being wound up or sequestrated or is under a scheme of arrangement aimed at avoiding winding up or sequestration. ${ }^{72}$

The section reinforced the common law position that a contract of employment was personal in nature and could not be transferred without the consent of the employee. An exception applied where an economic entity

\footnotetext{
Driver "Commercial Perspective on Section 197 of the Labour Relations Act" 2000 ILJ 910.

Grogan June 2002 EL 9.

Grogan and Gauntlett June 1999 EL 14.

S197(1)(a).

Grogan and Gauntlett June 1999 EL 14.
} 
was taken over and remained in existence. Here, the contracts of employment were automatically transferred. ${ }^{73}$ In other words, the commonlaw rule against non-consensual transfer of contracts of employment was entrenched, except in the case of transfers so described or insolvencies. ${ }^{74}$

The consequences foreseen by the original section 197 came into play only once it has been established that the business (or trade or undertaking) has been transferred as a going concern. ${ }^{75}$

Furthermore, "anything done before the transfer by or in relation to the old employer, will be considered to have been done by or in relation to the new employer". ${ }^{76}$

The original section 197 only dealt with individual contracts of employment and not collective agreements.

The contracts of employment to be transferred were those in existence immediately before the transaction and which must be transferred automatically. ${ }^{78}$

Section 197 (the original) tried to strike a balance between commercial interests and social policy. ${ }^{79}$ For a transfer of a business to be covered by the then section 197, two requirements were to be met. Firstly, that an economic entity, consisting of an organised grouping of resources, was transferred, and secondly, the economic entity retained its identity after the transfer. Outsourcing and subcontracting would in most cases not constitute a section 197 transaction based on this definition. ${ }^{80}$

Although the original section 197 did not give rise to as much litigation as might have been expected, it was generally accepted that the provision meant what it apparently said. Whenever an employer agreed to transfer the whole or part of its business to another employer, the new employer had to take the employees of the transferring employer into its service whether or not it wished to do so. The employers had no choice in the matter; unless the employees of the transferring employer agreed otherwise, a business could not be sold, merged or otherwise transferred without the whole or affected part of the workforce of the transferred business. ${ }^{81}$ The only way in which the new employer could avoid taking over the old employer's employees was to decline to accept the transfer of the business. ${ }^{82}$

\footnotetext{
Beaumont 19993 Beaumonts Service Beaumont Express 556.

Grogan and Gauntlett June 1999 EL 14.

Olivier and Smit "Transfer of a Business, Trade or Undertaking" September 1999 De Rebus 83.

$\mathrm{S} 197(2)(\mathrm{a})$.

Beaumont 19991 Beaumonts Service Beaumont Express 58.

Beaumont 19994 Beaumonts Service Beaumont Express 303.

Olivier and Smit September 1999 De Rebus 83.

Beaumont 19994 Beaumonts Service Beaumont Express 302.

Grogan June 2002 EL 9.

lbid.
} 


\section{Case law relating to the original section 197}

\section{Schutte $v$ Powerplus Performance (Pty) $L t d^{83}$}

The question was whether the contracting-out of a service or function (namely the servicing of vehicles) from the first respondent (its core business being the rental of vehicles) to the second respondent constituted a transfer as a going concern for purposes of section 197. The applicants alleged that there was a transfer of a part of the business as a going concern while the respondents alleged that there was actually a closure of its workshops and outsourcing of its services and maintenance work. ${ }^{84}$

Everything depended on whether the agreement entered into amounted to a transfer of the whole or part of the business. If that were the case, the new employer would assume all the rights and obligations that the old employer had towards its former employees, which would include the obligation to go on paying them what they had previously earned. The two employers predictably argued that what had happened was not a transfer of business, but the closure of the workshops and an "outsourcing" of its services and maintenance work. ${ }^{85}$

If the transaction was a closure of the workshops, then the staff concerned would have to be retrenched. Alternatively, if there had been a transfer of the undertaking, then section 197 would have applied with the result that the existing staff would have automatically been transferred to the new employer on their existing terms and conditions of employment. The court considered a number of factors and found them to be in favour of an undertaking, the most significant of which was that the economic entity of the workshops remained after the event. ${ }^{86}$

Seady AJ held that section 197 struck to the very heart of the conflict between the employer's interest in the efficiency or survival of the undertaking and the employees' interest in job security.

Seady AJ was able to distil an approach:

"that examines substance and not form; that weighs the factors that are indicative of a transfer of business from those that are not; that makes an overall assessment of the facts, not treating any one as conclusive in itself."

The court considered the following factors:

- The transfer was contractually foreseen.

- Stock was to be taken over.

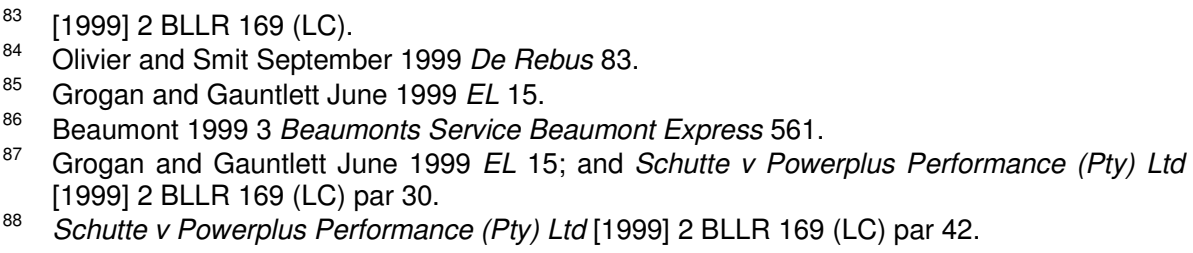


- The new employer was to use the same premises.

- There was almost no interruption in the continuation of the workshop activities by the new employer.

- There was a limited transfer of management to the new employer.

- A close relationship existed between the old and new employer, in the sense that the old shareholder held $50 \%$ of the shares in the new concern. ${ }^{89}$

However, the court found it unnecessary, given the indications of a transfer, to decide the question that an outsourcing operation could fall within the terms of section $197 .^{90}$

The Court did not expressly hold that a transfer of the whole or part of a business from one employer to another inevitably and ex lege results in the transfer of the contracts of service between the old employer and its employees to the new employer. The Court held that the contracts had been transferred as a result of the sale of the business by which they had previously been employed. ${ }^{91}$

The court observed that section 197 ensured employees' continuity of employment when their employers changed. ${ }^{92}$

\section{Foodgro (A division of Leisurenet Ltd) $\vee \mathrm{Kei}^{\mathrm{P}^{3}}$}

In Foodgro, Labour Appeal Court (LAC) was to determine objectively whether or not a particular transaction amounted to a transfer as a going concern in terms of the original section 197. An affirmative answer lead to the automatic transfer of employees to the buyer. ${ }^{94}$

Following a transfer of a going concern, Keil concluded a new contract of employment with the purchaser in terms of which she lost accrued service. She was retrenched and her severance pay was calculated on service with Foodgro and not with her former employer. She was successful in her challenge as section 197(4) guaranteed continuity of service with the new employer. ${ }^{95}$

The case concerned section 197(4) and not section 197(1); accordingly the judge's remarks regarding section 197(1) are not binding.

Froneman DJP's remarks included: ${ }^{96}$

- Purpose of the original section 197 was to protect employees and not to assist the purchaser as the common law did this.

89 Olivier and Smit September 1999 De Rebus 83.

90 Grogan and Gauntlett June 1999 EL 16.

91 Grogan and Gauntlett October 2000 EL 15.

92 Grogan June 2002 EL 10.

93 [1999] 9 BLLR 875 (LAC).

94 [1999] 9 BLLR 875 (LAC) 876 par F.

95 Beaumont 20025 Beaumonts Service Beaumont Express 138.

96 Foodgro (A division of Leisurenet Ltd) v Keil [1999] 9 BLLR 875 (LAC) 13. 
- The status quo benefits under section 197 secured advantages for employees not previously enjoyed.

- Employees transferred under section 197 could resign.

- New employees became subject to additional sanctions/remedies because of transfers of employment.

Foodgro made no attempt to define a going concern or to determine the intention behind section 197(1); it was unnecessary as section 197(4) was the focal point. ${ }^{97}$

\section{NEHAWU $v$ University of Cape Town: ${ }^{98}$ the Labour Court decision}

The first hint of a change of view occurred in this matter.

The Labour Court was called upon to decide whether the outsourcing of the university's cleaning, maintenance and gardening divisions amounted to a transfer of business for purposes of section 197 of the LRA. ${ }^{99}$ The university decided to outsource a range of non-core activities, sought to terminate the services of staff involved and invited them to seek employment with the service providers. ${ }^{100}$ The union primarily sought to have the contracts of employment transferred to the service providers and to have the terminations reversed. ${ }^{101}$ It argued that in section 197 situations, these contracts are automatically transferred and the specific outsourcing contracts constituted a section 197 transaction. ${ }^{102}$

Mlambo $\mathrm{J}$ was of the view that for an automatic transfer section 197(1) should state that it is permissible to transfer employment contracts without consent (this section says the opposite) and then in section 197(2) to describe the parameters and limitations where this happens. ${ }^{103}$

The contracts of employees affected by a transfer switch to the new employer only when the employers want them to; section 197 is there, not to ensure that the contracts of willing employees transfer, but that they will transfer without their consent if the employers so wish. ${ }^{104}$

Mlambo $\mathrm{J}$ held that it is in circumstances where employees do not consent to the transfer of their employment contracts and where the business is transferred as a going concern, that section 197 provides protection. ${ }^{105}$

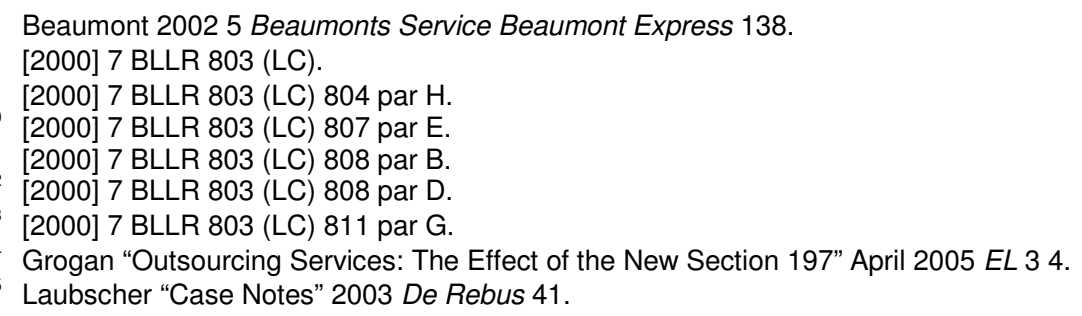


Mlambo $\mathrm{J}$ disagreed with the decision in Foodgro, which held that section 197 does provide for the automatic transfer of staff. The LAC in Foodgro referred to the "automatic transfers" of contracts of employment that took place as a result of the transfer of a business as a going concern. ${ }^{106}$ However, Mlambo $\mathrm{J}$ was bound by the Foodgro decision as it was handed down by a superior court. ${ }^{107}$

Mlambo $\mathrm{J}$ questioned the decision in Foodgro, but held that he was bound by the finding. He felt that section 197 will only apply when the employers agree that the contracts of employees will be transferred. In his regard, Foodgro took the opposite view.

The impression created by the Foodgro and the Powerplus decisions was that once it is established that there has been a transfer of a business as a going concern, it followed that the rights and obligations that existed between the old employer and the affected employees have by operation of law been transferred automatically to the new employer, who is obliged to employ those employees. ${ }^{109}$

Mlambo $\mathrm{J}$ took issue with this view, and he pointed out that section $197^{110}$

"prohibits the transfer of employment contracts without the consent of the employees concerned. The section provides, however, that employers may transfer employment contracts without the consent of the employees concerned where he transfers his business or part thereof as a going concern.

In other words, the provisions of section 197 become relevant where the

transfer of employment contracts without their consent is contemplated."11

Mlambo J's view is that section 197 simply overcomes the common law problem that contracts cannot be transferred without consent, and gives the buyer and seller the choice whether or not to transfer, but where the decision to transfer is made then the employees are protected under section 197(2) and (4) in the preservation of conditions of service, unless otherwise agreed. ${ }^{112}$

While recognising that outsourcing contracts could, in certain circumstances, amount to a transfer of a part of a business, the Labour Court in University of Cape Town held that the contracts in question did not have that effect. The test is whether, in substance, the transaction indicates a transfer of business. ${ }^{113}$

The Labour Court held that, while it is possible for an outsourcing contract to be permanent and involve the transfer of assets, thus classifying it as a

\footnotetext{
Grogan and Gauntlett October 2000 EL 15.

[2000] 7 BLLR 803 (LC) 813 par D.

[2000] 7 BLLR 803 (LC) 813 par E.

Grogan and Gauntlett October 2000 EL 15-16.

10 Grogan and Gauntlett October 2000 EL 16.

1 NEHAWU v University of Cape Town [2000] 7 BLLR 803 (LC) par 17.

[2000] 7 BLLR 803 (LC) 811 par J.

113 Grogan and Gauntlett "Case Roundup: Latest Judgments and Awards" August 2000 EL 25.
} 
transfer of part of the contractor's business, the outsourcing contracts at issue were not of that nature. ${ }^{114}$

Mlambo $\mathrm{J}$ held, however, that the outsourcing did not constitute a transfer of a going concern as envisaged by section 197 and declined to grant the relief sought. ${ }^{115}$ Only parts of the services concerned had been outsourced and the university had retained supervisory powers. Moreover, it could not be said that the outsourcing contracts amounted to a transfer of parts of the university's business "as a going concern". ${ }^{116}$

Whilst the university had identified non-core activities, it decided to retain certain of them as in-house and split those which were outsourced to multiple providers. Managerial and supervisory staff, particularly in the cleaning section, were retained as a control measure. In essence only some parts of the activities were outsourced. Linkages back to the university were pronounced. The contracts were not permanent; the functions were capable of being performed in-house later on. ${ }^{117}$

On the facts the Labour Court found that the outsourcing did not constitute a transfer of a going concern and refused the union the relief it sought. ${ }^{118}$ The court accordingly refused to grant a declarator that the outsourcing would have the effect of automatically transferring the contracts of the affected university employees to the contracting companies. ${ }^{119}$

The court felt that the case law on section 197 was wrong and that this section does not provide for the automatic transfer of employment. The contracting parties have a choice whether or not to effect the transfers of employment. This was a commentary or obiter and does not amount to case law. ${ }^{120}$

Instead of placing emphasis on section 197(2)(a), as earlier judgments had done, Mlambo $\mathrm{J}$ chose to focus on the introductory words of section $197(1)$. By doing so, he interpreted the provision as a whole as if it dealt only with situations in which the contracts of the employees had in fact been transferred without their consent. It was only when section 197 was read in this way, said Mlambo J, that the employees were protected by the provision stipulating that the new employer would for all intents and purposes take the place of the old employer. ${ }^{12}$

The apparently radical conclusion which Mlambo $\mathrm{J}$ arrived at was this: ${ }^{122}$

"Thus an employer in the process of transferring his business or part thereof has a choice whether to also transfer the contracts of employment attached to

\footnotetext{
4 Grogan and Gauntlett August 2000 EL 26.

[2000] 7 BLLR 803 (LC) 816 par G.

116 Grogan and Gauntlett August 2000 EL 26.

117 [2000] 7 BLLR 803 (LC) 816 par J.

18 [2000] 7 BLLR 803 (LC) 817 par I.

119 Grogan and Gauntlett August 2000 EL 26.

120 Beaumont 20004 Beaumonts Service Beaumont Express 323.

121 Grogan June 2002 EL 10.

122 Ibid.
} 
that business or not. If he decides to transfer those contracts, section 197 kicks in."

According to this analysis, the University of Cape Town was not obliged to transfer the contracts of employment of the affected workers to the contracting companies, as NEHAWU claimed the university was bound to do. This finding would have disposed of the matter had Mlambo $J$ not thought that he was bound to follow the contrary view expressed by the LAC in Foodgro. ${ }^{124}$

\section{З 331 Two circumstances}

Which view is correct? Section 197(2)(a) deals with the transfer of rights and obligations from the "old" to "new" employers in the event of transfers of businesses as "going concerns". However, section 197(2)(a) must be read with section 197(1)(a) to which it expressly refers. ${ }^{125}$ Rights and obligations only transfer automatically from one employer to the other if the business is transferred "in the circumstances referred to in subsection (1)(a)". ${ }^{126}$

The difference between Mlambo J's interpretation of section 197(2)(a) and that adopted in Foodgro and Powerplus turns on what circumstances are envisaged in the cross-reference to section 197(1)(a). ${ }^{127}$

When section 197 is read as a whole, it is clear that it is intended to be permissive. What circumstances did the legislature have in mind when it referred in section 197(2)(a) to section 197 (1)(a)? Two sets of circumstances are implicitly envisaged in section 197(1): first, that the contracts are transferred without the employees' consent; second, that there is a transfer of business as a going concern. These are the circumstances that must exist before the transferring employer can rely on section 197(1)(a). ${ }^{128}$

In the interpretation of section 197(2)(a), Foodgro and Powerplus place emphasis on the second circumstance; and University of Cape Town, on the first. ${ }^{129}$

Is Mlambo J's interpretation of section 197 correct? Grogan is of the view that what he appears to have overlooked, with respect, is that the crossreference in section 197(2)(a) is specifically to section 197(1)(a). If section $197(1)(a)$ is read in isolation, it refers to one condition only, namely, that "the whole or any part of a business, trade or undertaking is transferred by the old employer as a going concern". 130

\footnotetext{
NEHAWU v University of Cape Town [2000] 7 BLLR 803 (LC) par 21.

Grogan June 2002 EL 10.

25 Grogan and Gauntlett October 2000 EL 16.

S197 (prior to 2002 amendments).

Grogan and Gauntlett October 2000 EL 16.

28 Grogan and Gauntlett October 2000 EL 16.

Ibid.

Grogan and Gauntlett October 2000 EL 17.
} 
If that phrase had been used in section 197(2)(a), the meaning of the latter provision would have been clear: provided that there is a transfer of the business as a going concern, the old employer's rights and obligations in respect of its employees transfer automatically to the new employer. ${ }^{131}$

Read thus, section 197(1) and (2) fulfill distinct purposes. The former provision permits employers involved in sales, mergers and the like to transfer employees without their consent if they wish to do so when a business is transferred as a going concern. Section 197(2) ensures that, whenever a transfer of a business as a going concern occurs, the contracts of affected employees transfer as well, whether the employees like it or not. On this reading, it does not follow that, because section 197(1) permits an employer to transfer affected workers without their consent, the employer can decide not to transfer affected workers if they wish to be transferred. The "agreement" referred to in section 197(2)(a) has nothing to do with the "consent" mentioned in section 197(1). The proviso that the contracts of employment of the workers concerned will transfer automatically "unless otherwise agreed" is aimed at ensuring that employees who face transfer as a consequence of a sale or merger of the business of their employers can renegotiate certain terms of their contracts, as was found to be their right in Foodgro. ${ }^{132}$

\section{332 Second hurdle}

Although the court in University of Cape Town disagreed with the Foodgro judgment, it noted correctly that Foodgro only assisted NEHAWU over the first hurdle. The second hurdle faced by the union was the requirement that it prove that the outsourcing arrangements, in fact, amounted to transfers of parts of the University of Cape Town's business as going concerns. ${ }^{133}$ This was whether the outsourcing of the University of Cape Town's gardening, cleaning and maintenance divisions amounted to a transfer of part of the university's business "as a going concern". ${ }^{134}$

On the face of it a company's decision to bring in an outsider to perform services previously rendered by its employees amounts to a "transfer of part of its business as a going concern". That the function so transferred is not part of the transferor's core business does not matter. However reluctantly it may perform the task, maintaining grounds and gardens is part of a university's business. ${ }^{13}$

For the purposes of section 197, the court held that the test was whether or not the entity that was sold was an economic entity that was still in existence; this would be the case where its operation was actually being

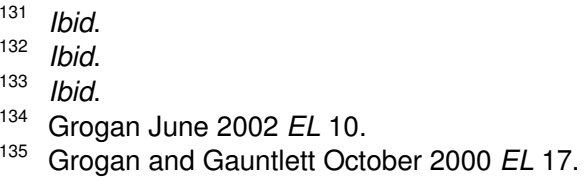

135 Grogan and Gauntlett October 2000 EL 17. 
continued or had been taken over by the new employer with the same or similar activities. ${ }^{136}$

In order to establish whether outsourcing amounts to the transfer of a business, the nature of outsourcing must be examined. According to Mlambo $\mathrm{J}$, there are marked differences between outsourcing and the sale or merging of businesses. This is how he described them: ${ }^{13}$

"Outsourcing involves the putting out to tender of certain services for a fee.
The contractor performs the outsourced services and in return is paid a fee for
its troubles by the employer. Where outsourcing occurs the employer pays the
contractor a fee to render the services outsourced as opposed to paying
salaries or wages to a group of employees to render the outsourced service.
An outsourcing transaction is usually for a fixed period of time at the end of
which it again goes out to tender and the existing contractor could lose the
contract to another contractor."138

Upon the sale or merger of a business, on the other hand, the business or part of the business changes hands permanently. The seller relinquishes control over the business forever. For Mlambo $\mathrm{J}$ the impermanence of outsourcing contracts and the permanence of sales provide the key to why section 197 applies in respect of the former but not in respect of the latter. ${ }^{139}$ As Mlambo J pertinently asked, if section 197 were to result in the automatic transfer of the outsourced employees from the employer to the contractor, what happens if the employer subsequently exercises its contractual right to cancel the outsourcing contract and award it to another contractor? Section 197 clearly does not deal with such a situation. ${ }^{140}$

It cannot be contended that the workers' contracts transfer automatically from the one contractor to the other, because, even if the change amounts to a transfer of business from the one contractor to the other, such transfer is not effected by the "old employer", who is, of course, now the unsuccessful contractor. ${ }^{141}$

The only application section 197 can have in these circumstances is that to which it was put in Foodgro: namely, to ensure that employees who lose their jobs if the contractor decides to retrench them are given severance pay calculated according to their service with the first contractor and their period of service with the original employer. According to Mlambo $\mathrm{J}$ this can possibly be the case in some outsourcing arrangements, however, it was not the case in the arrangement contemplated by the University of Cape Town. ${ }^{142}$ Mlambo $\mathrm{J}$ ruled that the outsourcing was not a transfer of part of the university's business as a going concern, because the university had not

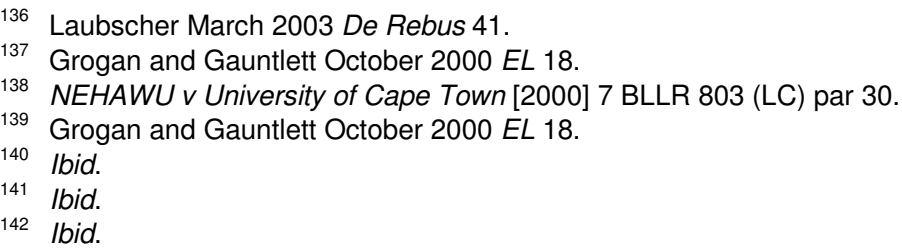


retained control over the work to the contractors, and because the arrangement with the contractors was not permanent. ${ }^{143}$

For Mlambo $\mathrm{J}$ the most significant of all consequences was that sales and mergers involve the permanent transfer of the business or parts of businesses, while most outsourcing arrangements are not permanent. It is not the business that is transferred, but merely the opportunity to perform the outsourced service. The outsourcing party has the right to decide who gets the contract to perform the outsourced service when the original contract expires. If the outsourcer chooses another contractor, what happens to the employees who were transferred to the original sub-contractor? ${ }^{14}$

Whether the conclusions drawn by Mlambo $\mathrm{J}$ in University of Cape Town is correct can be finally decided only by the Labour Court. Employers should not jump to the conclusion that outsourcing is a complete cure when it comes to rationalisation. ${ }^{145}$ Mlambo $\mathrm{J}$ makes it very clear that outsourcing does not relieve the employer of the duty to treat affected employees fairly. The University of Cape Town judgment indicates that an outsourcing arrangement will not escape the net of section 197 simply because it is called outsourcing or merely because the old employer is the only customer of the contracting company. ${ }^{146}$

In University of Cape Town, the university retained not only the right to review the outsourcing contracts periodically and put them out to tender again, but also retained the power to supervise and manage the manner in which the work handed out to the contractor was conducted. ${ }^{147}$ According to Mlambo $J$ these characteristics precluded him from finding that the outsourcing contracts amounted to a transfer of part of the university's business. An outsourcing contract will qualify as a transfer of business as a going concern only if the employer "relinquishes the power to dictate standards over the outsourced services". ${ }^{148}$

The Labour Court judgment did establish one firm principle, namely, to constitute a transfer of part of a business, the outsourcing arrangement must be permanent. ${ }^{149}$

The issue in this case was whether a "first-generation" outsourcing arrangement could attract the provisions of section 197. The Labour Court held that, because the first- or subsequent generation contractor could not possibly be bound by section 197 to transfer affected employees to the second or later, outsourcing itself did not constitute a transfer of business as a going concern. ${ }^{150}$

143 Grogan June 2002 EL 10.

144 Grogan April 2005 EL 5.

145 Grogan and Gauntlett October 2000 EL 18.

146 Ibid.

147 Ibid.

48 NEHAWU v University of Cape Town [2000] 7 BLLR 803 (LC) par 33.

149 Grogan April 2005 EL 5.

150 Grogan and Gauntlett October 2005 EL 11. 
The reasoning of Mlambo $\mathrm{J}$ in University of Cape Town (LC) was that outsourcing cannot constitute a transfer of business because, when a service is outsourced, the contractor does not gain control over the ultimate fate of the contract, control remains in the hands of the principal. ${ }^{151}$

\section{NEHAWU $v$ University of Cape Town: ${ }^{152}$ the LAC decision}

The question whether employers who are parties to a transfer of the whole or parts of businesses as going concerns can agree not to transfer the affected employees, split the LAC. ${ }^{153}$ Van Dijkhorst AJA (who wrote the majority judgment) and Comrie AJA agreed with the university's argument that employers can decide between them not to transfer employees, whilst Zondo JP thought otherwise. ${ }^{154}$

Van Dijkhorst AJA felt that the key to the correct interpretation of section 197 was its silence on whether employers who are parties to a transfer of business are required to agree to a transfer of affected employees. ${ }^{1}$

The most important indication for Van Dijkhorst AJA that the legislature intended to allow employers to choose whether to transfer employees along with businesses, lies in the concept of "business as a going concern". ${ }^{156}$ The judge wrote:

"A business is a going concern only if its assets, movable and immovable, tangible and intangible, are utilized in the production of profit (or, in the case of an undertaking, the attainment of its goals). In every business its employees are a vital component and in labour intensive industries the major asset. To say that there can be a sale of business as a going concern without all or most of the employees going over is to equate a bleached skeleton with a vibrant horse. A going concern is 'one in actual operation ...' That cannot be the case where there is no workforce."

The purchasers and sellers of businesses "as going concerns" are free to define what is included in that concept. This interpretation of "going concern" enables the employers to ensure that their transaction escapes the provisions of section 197 by simply agreeing not to include all or most of the employees of the transferor. Where they do so, the transaction does not amount to a "transfer of a business as a going concern", it is a "bleached skeleton, not a vibrant horse" and the people who gave life to the "horse" have no say in the matter (their exclusion from the transaction renders it immune by definition from the reach of section 197). ${ }^{158}$ Where the seller and the purchaser agree that the employees are not part of the transaction, the

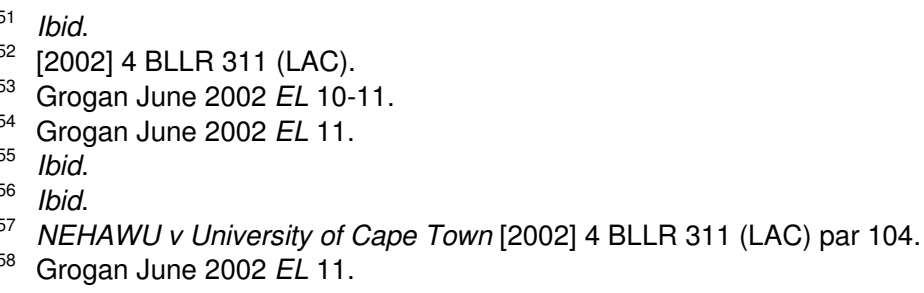


transaction does not amount to a transfer as a going concern and the provisions of section 197 do not apply. ${ }^{159}$

For the majority this conclusion was the end of the inquiry. The University of Cape Town and the respondent contractors were legally entitled to agree that the university's garden, cleaning and maintenance workers could choose between applying for posts with the contractors or being retrenched by the university. ${ }^{160}$ That meant that the outsourcing arrangements did not amount to a transfer of part of the university's business as a going concern and thus NEHAWU's appeal had to fail. ${ }^{161}$

It was the term "going concern" that led Van Dijkhorst AJA to conclude that the transfer of a business without its staff did not attract the provisions of section $197 .{ }^{162} \mathrm{~A}$ "going concern" must, in the opinion of the majority, include the employees. ${ }^{163}$ Zondo JP (who wrote the minority judgment) did not agree that the transfer of a business without its employees cannot in any circumstances amount to the transfer of a business as a going concern. ${ }^{164}$ Zondo JP pointed out that the question whether a business has been transferred as going concern is a matter for objective determination on the facts of each case. ${ }^{165}$

Zondo JP set out a number of factors relevant in determining whether a business has been transferred as a going concern and stated that the decisive criterion for establishing the existence of a going-concern transfer is whether the entity in question retains its identity. ${ }^{166}$

Zondo JP reasoned that, if a business can be deemed to be transferred as a going concern even without its employees, it follows that the mere fact that the employers agree, the employees of the transferors will not be transferred, is not in itself sufficient to render the transaction something other than the transfer of a business as a going concern. ${ }^{167}$

The majority of the three-judge bench decided that the legislature intended primarily to protect employees against forced transfers and to facilitate business transfers, but held that even on its interpretation, section 197 "is not without advantage to employees", without specifying what those advantages are. ${ }^{168}$

However, Zondo JP, following the judges in Foodgro, held that the purpose is to protect employees from losing their jobs when their employers' businesses change hands. ${ }^{169}$ There can be little doubt that Zondo JP's

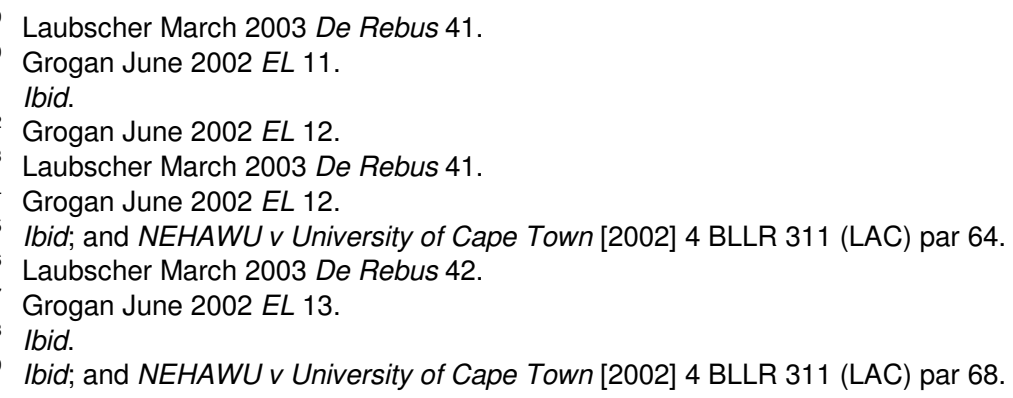


assessment of the purpose of section 197 is correct. The idea that the legislature intended only to protect the right of employees not to be transferred without their consent is far-fetched. Since that right is in any event entrenched in the common law, there was no need to enact a special statutory provision to protect it. However, a statute can only be applied in the manner in which it is intended to be applied, if its wording allows it to be so applied. ${ }^{170}$

The majority of the LAC held that Foodgro had been incorrectly interpreted and that section 197 transfers of employment only arise where two employers agree that the contracts of employment will be transferred. The LAC's finding included: ${ }^{17}$

- The alteration of the common law on a consensual transfer of employment is more onerous than common law. The statute did not intend to burden the purchaser further.

- It is correct that the status quo benefits under section 197 secure advantages for employees not previously enjoyed. If intended to mean that automatic transfers occur not only in case of consensus, then no reasons are given.

- It is correct that employees transferred under section 197 can resign.

- It is also correct that new employees are subject to additional sanctions/remedies because of transfers of employment.

The majority of the LAC held that the decision in Foodgro does not stand in the way of a finding that section 197(1) is to be interpreted to limit its scope to the situation where the seller and the purchaser define the transaction as the sale of a business as a going concern (employees included). The LAC held that Mlambo $\mathrm{J}$ in the Labour Court was correct that the consensual transfer of contracts of employment is a prerequisite for its operation. ${ }^{172}$

The LAC held that a transfer of a going concern is a subjective test dependent upon the agreement of the old and new employers. ${ }^{173}$

The LAC did not address the question whether an outsourcing contract could be a transfer of a going concern. ${ }^{174}$ Given the terms on which this matter was argued and decided, there was no need for the court to decide on the second issue raised by the judgment of the court a quo, namely, whether the outsourcing arrangements entered into by the university amounted to transfers of parts of its business as going concerns. ${ }^{175}$

\footnotetext{
170 Grogan June 2002 EL 13.

171 [2002] 4 BLLR 311 (LAC) 348 par F-G.

172 [2002] 4 BLLR 311 (LAC) 348 par I.

173 Beaumont "Legislation and Strategy: Labour Law Changes - The Consequences" 20025

Beaumonts Service Beaumont Express 148.

174 Beaumont 20025 Beaumonts Service Beaumont Express 139.

175 Grogan June 2002 EL 14.
} 
The effect of this matter under the original section 197 was that employers who wished to dispense with and acquire businesses are free to agree that the transferor's employees will not be taken into employment by the transferee, and to arrange the terms of the transfer accordingly. However, the old employer will then have to retrench its employees in accordance with the provisions of section 189 of the LRA. ${ }^{176}$

This judgment was handed down on the eve of the replacement of section 197 by a wholly revised provision that leaves no doubt about the legislature's intention to deprive employers of the right to decide whether employees will retain their jobs when businesses are transferred. A court cannot have regard to a pending amendment when interpreting an existing statutory provision, but it is worth asking whether the majority's interpretation of the original section 197 would survive the amendment. ${ }^{17}$

\section{NEHAWU $v$ University of Cape Town: ${ }^{178}$ the Constitutional Court decision}

The Constitutional Court (CC) upheld the view of the minority and overruled the majority judgment. ${ }^{179}$ The CC held that the original section 197 resulted in the automatic transfer of the old employer's contracts of employment, a ruling confirmed by the new section 197 .

The purpose behind section 197 prior to the amendments was debated and defined in this Constitutional Court (CC) matter. This finding is important in assisting all stakeholders in understanding the intention behind section 197 and the balance that it offers to both employers and employees. ${ }^{181}$

Section 197 offers assistance to both employers and employees by amending some of the consequences which otherwise would have occurred through the common law. Without section 197, employees could resist being transferred to a new employer and potentially could hold the seller to ransom over a potential transfer of a going concern. ${ }^{1}$

Section 197 has a dual purpose - facilitating commercial transactions and protecting workers against unfair job losses. ${ }^{83}$ Properly construed section 197 was for benefit of both employers and workers. ${ }^{184}$

According to the CC the construction placed on section 197 by the majority judges in NEHAWU $v$ University of Cape Town (LAC), erred in two respects:

- the first error was to misrepresent the meaning of going concerns; and

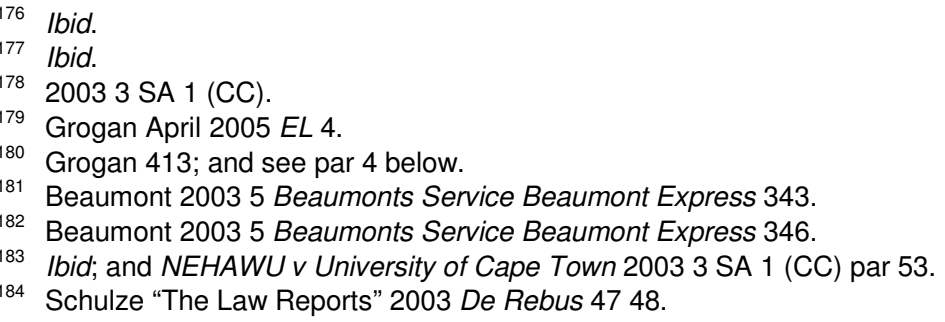


- the second was to ignore the legislature's intention to protect jobs. ${ }^{185}$

Ngcobo $\mathrm{J}$ considered the meaning of the phrase "going concern" and held that it should be given its ordinary meaning, which is a "business in operation so that the business remains the same but in different hands". ${ }^{18}$

Whether a business is transferred depends on substance and not form; this is an objective test determined in light of the facts of each transaction. The CC thus found the LAC was incorrect in its interpretation of section 197, even though there was no agreement between the university and the outsource service providers to take over staff, this did not prevent the labour court from enquiring into and making a finding whether outsourcing was a transfer of a going concern. ${ }^{187}$ Each transaction must be considered on its own merits and regard must be had to substance rather than form. ${ }^{188}$

The CC did not deem it necessary to discuss the phrase "transfer of business as a going concern", and the judgment leaves the labour courts free to apply that concept on a case-by-case basis, subject only to the proviso that a court cannot rule that a business is not transferred as a going concern solely because the employers have agreed not to transfer the affected employees. ${ }^{189}$

The CC found it unnecessary to deal with the outsourcing issue, as this entailed questions, which the LAC had not considered and the matter was remitted to the LAC for decision on that point. ${ }^{190}$ It therefore remains possible that the LAC may still find that the outsourcing arrangement entailed only the transfer of the "bleached skeleton" of the university's gardening, cleaning and maintenance division. ${ }^{191}$

If the LAC overrules Mlambo J's ruling that the outsourcing arrangement did not constitute a transfer of parts of the business of the university as a going concern, the sub-contractors will be obliged to take on the retrenched university employees. But if for any reason the LAC upholds the Labour Court judgment, the matter could well come before the CC again. ${ }^{192}$

Unfortunately for the development of our law, the parties decided to settle the matter without returning to court. In any event, that issue would have been academic, because soon after the CC laid down the true meaning of the original section 197, the legislature stepped in and tried to clarify its intention with a new version of that provision. The new version confirmed the view of Zondo JP in the minority judgment of the University of Cape Town (LAC) matter and the CC, namely that section 197 was intended to give

185 Grogan and Gauntlett "Going Concerns" February 2003 EL 1820.

186 Laubscher March 2003 De Rebus 42.

187 Beaumont 20035 Beaumonts Service Beaumont Express 347.

188 Laubscher March 2003 De Rebus 42.

189 Grogan and Gauntlett February 2003 EL 21.

190 lbid.

191 Grogan and Gauntlett February 2003 EL 22.

192 lbid. 
blanket protection to employees whose employers transfer a whole or part of their businesses as going concerns. ${ }^{193}$

Another issue which lay at the heart of the University of Cape Town dispute remained unresolved, namely whether outsourcing constitutes a transfer of business as a going concern.

\section{The amendment of section 197 of the LRA}

The original section 197 was described as a "legal monstrosity". It was a section that gave rise to a great deal of uncertainty in that the answers to crucial questions relating to its applicability and its consequences were not discernable in its provisions.

It was anticipated that the amended section 197 would resolve the dispute over the extent of protection enjoyed by workers whose employers' businesses are sold or absorbed by another company. ${ }^{195}$

According to the Labour Relations Act Amendment Bill, ${ }^{196}$ if a transfer of the whole or part of a business as a going concern takes place, the new employer is "automatically substituted for the old employer in respect of all contracts of employment in existence immediately before the date of transfer" and - to remove all possible doubt - "all the rights and obligations between the old employer and each employee at the time of the transfer continue in force as if they had been rights and obligations between the new employer and each employee". ${ }^{197}$

In a departure from the original section 197, the new employer in the transfer of a going concern inherits the collective dynamics of the old employer including recognition agreements, arbitration awards and extension of bargaining council agreements. ${ }^{198}$

The reach of the amended section 197 clearly extends beyond transfers consequent on a sale of a business. Any corporate event such as a merger, take-over, or other restructuring potentially falls within the ambit of section 197 , as does an exchange of assets, donation and outsourcing of non-core functions or business activities.

Transfers of going concerns are dealt with in section 197; and section 197A deals with the transfer of going concerns out of liquidations or insolvencies. Section 197B deals with disclosure over pending financial difficulties and insolvencies.

193 Grogan April 2005 EL 4.

194 Bosch "A Survey of the 2002 Labour Legislation Amendments: Is There Really 'Something for Everyone'?" 2003 ILJ 2348.

195 Grogan and Gauntlett October 2000 EL 3.

196 [B77-2001].

197 Grogan June 2002 EL 14.

198 Beaumont 20025 Beaumonts Service Beaumont Express 148.

199 Van Niekerk et al 303. 
The amendments have shied away from defining what constitutes a transfer of a going concern. ${ }^{200}$

For there to be a transfer, there must be a shifting of a business entity by one employer to another. This assumes that there must be at least two distinct employers involved in the transaction. A transfer can therefore be effected by means of a sale or some kind of disposition, or by operation of law. It does not matter whether the transfer is effected by a series of two or more transactions. The courts have stated that this enquiry ultimately depends on fact and degree. ${ }^{201}$

Whilst each transaction is to be examined on its merits, a transfer of a going concern can be distinguished from a purchase of assets and most subcontracting exercises, characteristics of a transfer of going concerns will be the acquisition of brand names, people and business locations. ${ }^{202} \mathrm{~A}$ proper section 197 transaction results in the buyer or new employer inheriting all the employees in the transferred concern. ${ }^{203}$

Problematic areas of the amendments include the elaborateness of the new section 197 and section 197A transfers including the omission to define what constitutes a going concern. ${ }^{204}$

The retention of the phrase "as going concerns" in the amended section 197 leaves the issue regarding whether outsourcing arrangements amount to transfers of part of businesses as going concerns, open for debate. ${ }^{205}$

Beaumont 20025 Beaumonts Service Beaumont Express 148.

201 Van Niekerk et al 303.

202 Beaumont 20025 Beaumonts Service Beaumont Express 148.

203 Beaumont 20025 Beaumonts Service Beaumont Express 149.

204 Beaumont 20025 Beaumonts Service Beaumont Express 154.

205 Grogan June 2002 EL 14. 